Supplement of Saf. Nucl. Waste Disposal, 1, 285-286, 2021

https://doi.org/10.5194/sand-1-285-2021-supplement

(c) Author(s) 2021. CC BY 4.0 License.

Supplement of

\title{
Stress factor human activities
}

\author{
Anne Eckhardt \\ Correspondence to: Anne Eckhardt (anne.eckhardt@risicare.ch)
}

The copyright of individual parts of the supplement might differ from the article licence. 


\section{Hit.ititransens}

TRANSDISZIPLINÄRE FORSCHUNG ZUR ENTSORGUNG HOCHRADIOAKTIVER ABFÄLLE IN DEUTSCHLAND

\section{Stressfaktor Mensch}

Stress factor human activities

Anne Eckhardt

Forschungssymposium SafeND, Berlin 10 to 12 November 2021 


\section{Repository safety requirements}

- EndISiAnfV

- Category «Developments based on future human activities»

- To be taken into account when optimising the repository system and verifying its robustness

- Reference developments are developments that can be induced by human activities which are common in the present

- Can «futurology» contribute to optimising the long-term safety of a repository? 


\section{Scenario development}

Assumptions:

- Sealed repository

- Compliance with safety requirements

- Time horizon up to approx. 100 years

- Societal values unchanged 


\section{Scenario area with 25 «point scenarios»}

Fundamentals:

- Potential impacts on the repository

- Drivers and trends

- Future narratives

- Findings and ideas from scientific literature and science fiction

- Experiences in the field of radioactive waste management

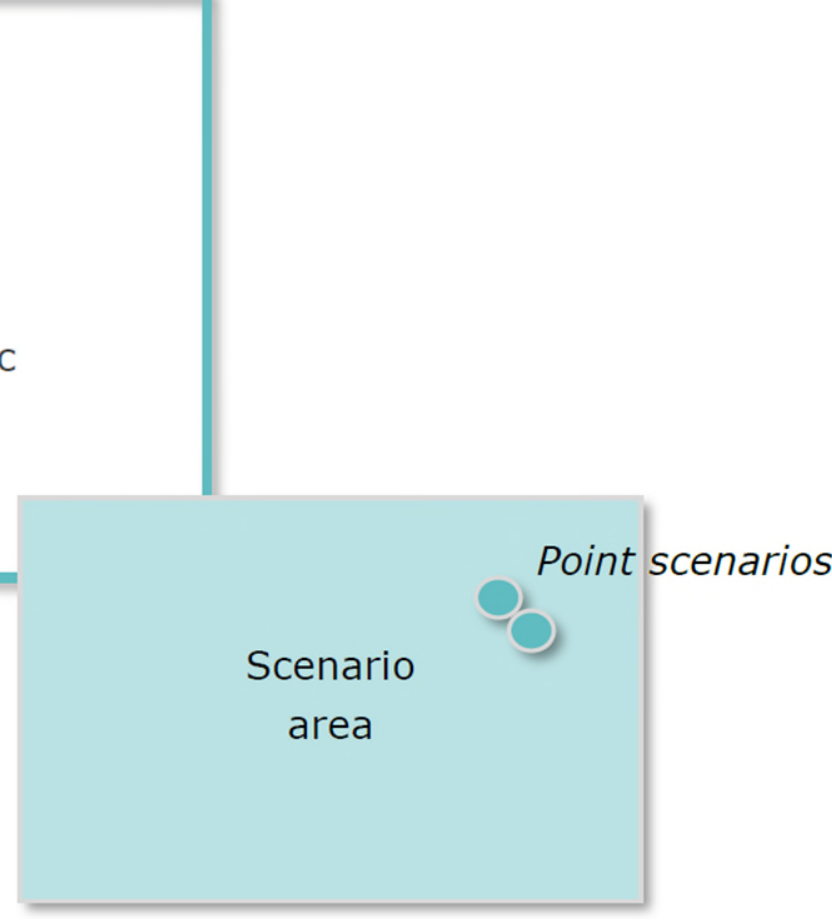




\section{Example of a scenario}

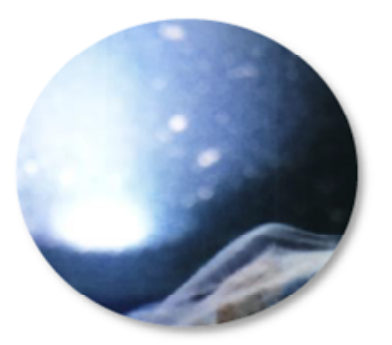

\section{Absturz}

$>$ Die Barrieren des Endlagers werden beim Absturz eines großen Weltraumfahrzeugs beschädigt.

Szenarium: Ein Weltraumfahrzeug für interplanetaren Verkehr mit erheblicher Frachtkapazität stürzt kurz nach dem Start auf die Erdoberfläche über dem Endlager ab. Durch die außergewöhnlich große Kraft, die auf die Erdoberfläche einwirkt, wird auslegungsüberschreitend Energie auf das Endlagersystem übertragen. In früheren Szenarienentwicklungen wurde auch über ein Kriegsweltraumschiff nachgedacht, das den Absturz vergeblich durch Abfeuern von Strahlung in den Untergrund abzubremsen versucht und damit die Schäden im Untergrund noch verstärkt.

Andere Ursache einer solchen unbeabsichtigten Krafteinwirkung könnten der Einschlag eines Meteoriten sein oder eine verheerende Explosion bei der Lagerung von Chemikalien. Das Szenarium weist Ähnlichkeiten zu Szenarien auf, bei denen Kernwaffen oder andere Waffen mit stark explosiver Wirkung zum Einsatz kommen.

Die übertragene Energie führt zu Schäden an den Barrieren des Endlagers und beeinträch- 


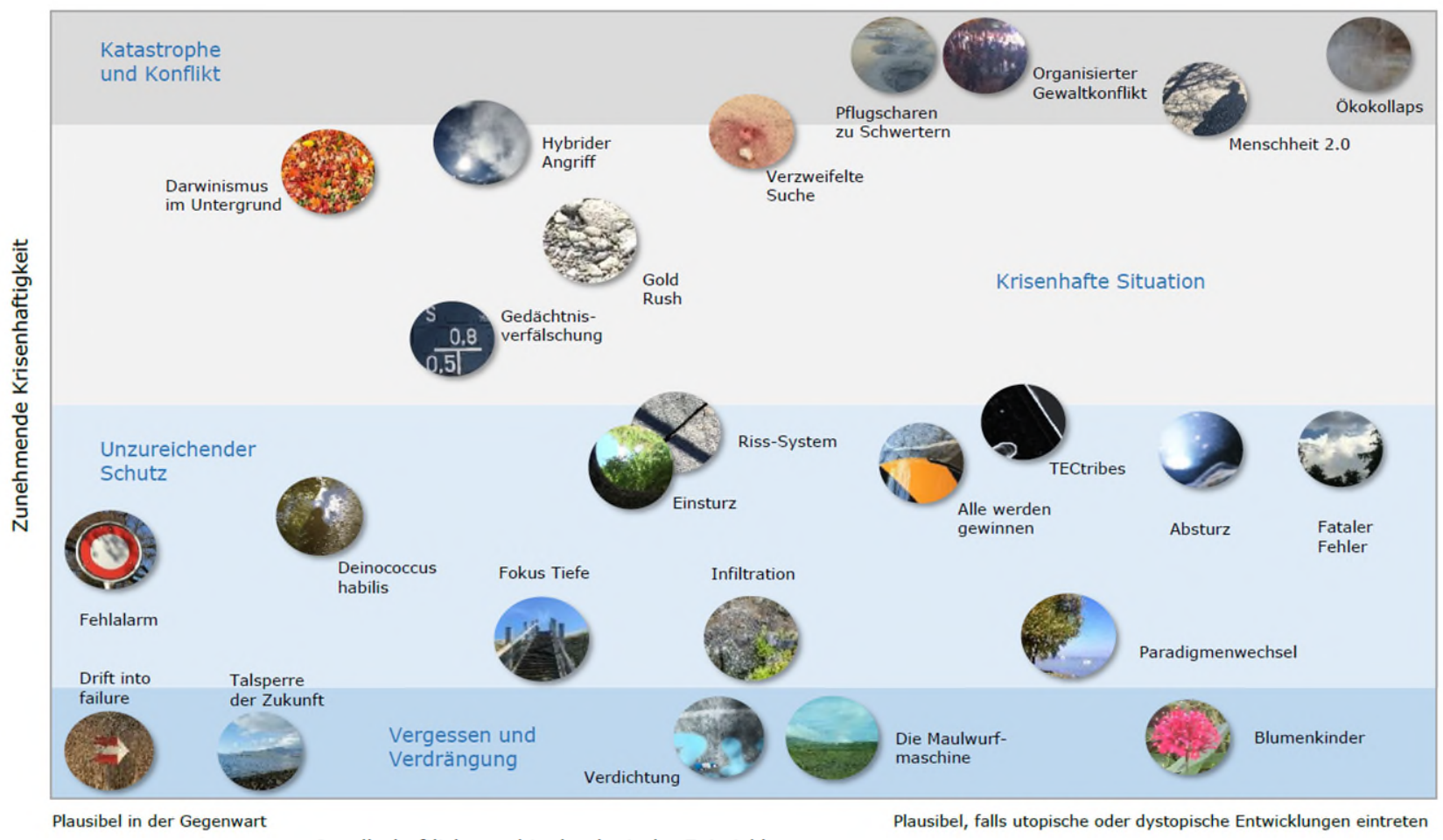

Gesellschaftliche und technologische Entwicklungen

Plausibel, falls utopische oder dystopische Entwicklungen eintreten

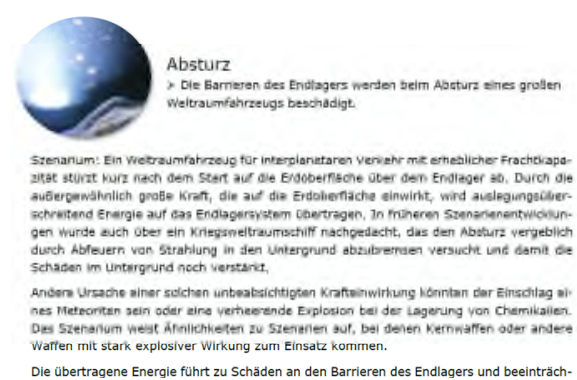

\section{îi:.i: \\ TRANSENS}




\section{Pivotal topics of the scenarios}

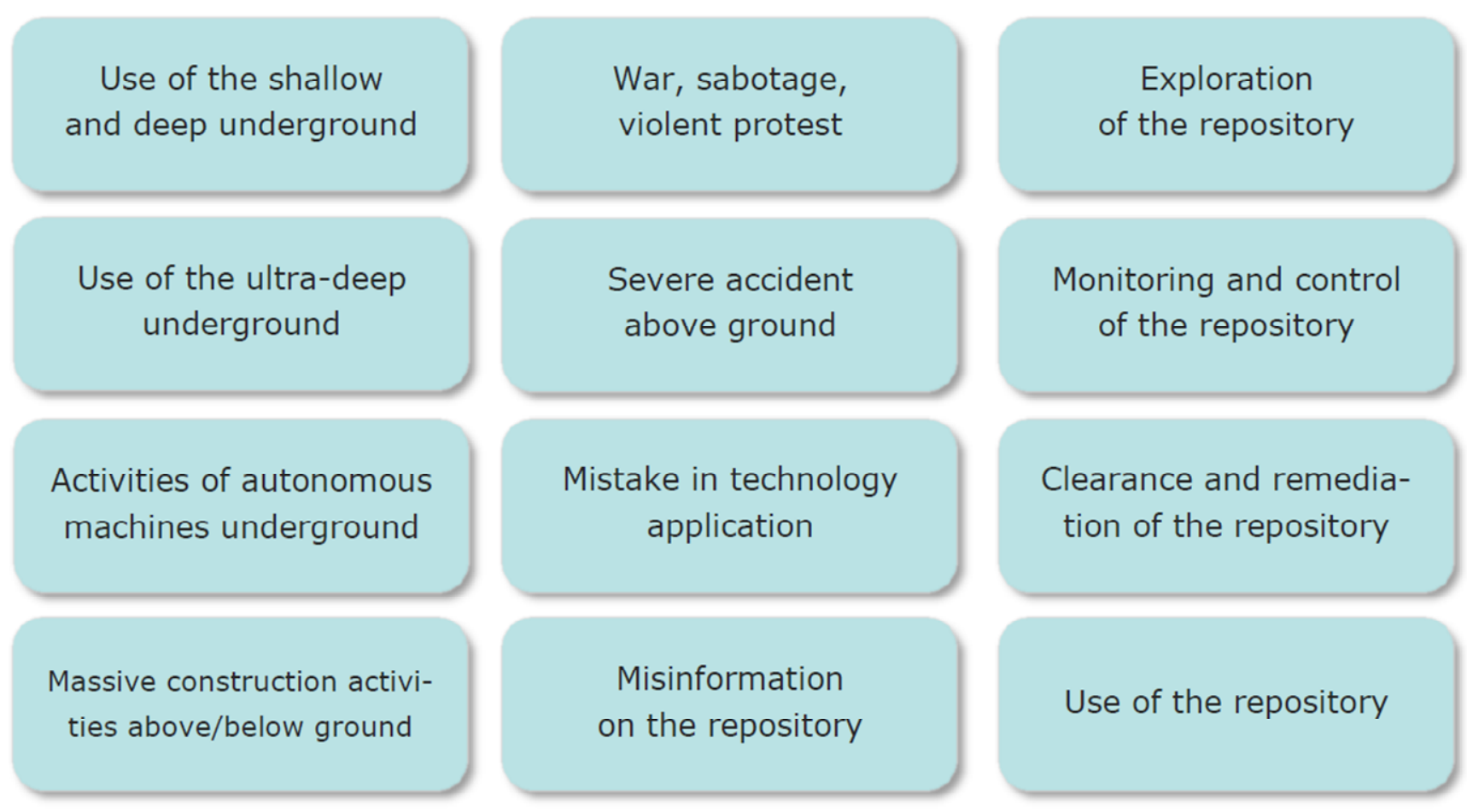

ithi:..: TRANSENS 


\section{Notes on optimisation}

\section{- to be refined and substantiated}

- Conceptual approaches

- e.g. Simple storage concept using widely available materials

- Technical

- e.g. Choice or design of barriers also with regard to resistance to microbial influences

- Informational

- e.g. Preparation and transmission of criteria and measures in case doubts arise about the safety of the repository

- Societal

- e.g. Design compensation measures in such a way that they do not contribute to a symbolic effect of the repository site 


\section{Conclusions}

- Relevance of subtle developments due to the use of the underground, e.g. in connection with climate change

- Damage to what humans value often to be expected with considerable delay

- Delimitation of intended and inadvertent human intrusion often unclear

- Great importance of society's perception of the closed repository and of the confidence in its safety

- Indications for optimisation and verification of robustness can be derived

- Scenarios of future human developments should accompany the safety investigations on the disposal pathway 


\section{Many thanks for your attention}

Gefördert durch:

Gefördert im Niedersächsischen Vorab der Volkswagenstiftung

:- VolkswagenStiftung

$\because \div$

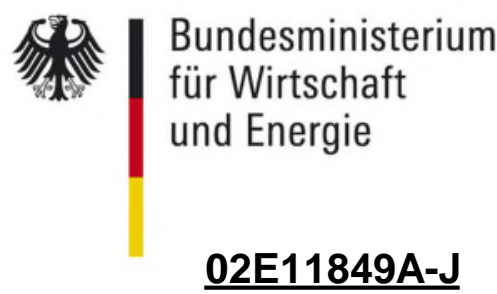

Niedersächsisches Ministerium

für Wissenschaft und Kultur

aufgrund eines Beschlusses des Deutschen Bundestages 